\title{
The orchid-bee faunas (Hymenoptera: Apidae) of 'Parque Nacional do Monte Pascoal', 'Parque Nacional do Descobrimento' and three other Atlantic Forest remnants in southern Bahia, eastern Brazil
}

\author{
Nemésio, A.* \\ Instituto de Biologia, Universidade Federal de Uberlândia - UFU, \\ Rua Ceará, s/n, Campus Umuarama, CEP 38400-902, Uberlândia, MG, Brazil \\ *e-mail: andre.nemesio@gmail.com \\ Received June 4, 2012 - Accepted July 12, 2012 - Distributed May 31, 2013 \\ (With 2 figures)
}

\begin{abstract}
The orchid-bee faunas of 'Parque Nacional do Monte Pascoal', 'Parque Nacional do Descobrimento' and three other Atlantic Forest remnants ranging from 1 to 300 ha in southern Bahia, eastern Brazil, were surveyed. Baits with seventeen different scents were used to attract orchid-bee males. Four thousand seven hundred and sixty-four males belonging to 36 species were actively collected with insect nets during 300 hours from November, 2008 to November, 2009. Richness and diversity of orchid bees found in this study are the highest ever recorded in the Atlantic Forest domain. Eufriesea dentilabris (Mocsáry, 1897) and Eufriesea violacea (Blanchard, 1840) were collected at the 'Parque Nacional do Monte Pascoal', the first record of these species for the state of Bahia and the northernmost record for both species. Females Exaerete dentata (Linnaeus, 1758) were also collected at 'Parque Nacional do Monte Pascoal' and old records of Eufriesea aeneiventris (Mocsáry, 1896) in this area makes this site the richest and most diverse concerning its orchid-bee fauna in the entire Atlantic Forest and similar to areas in the Amazon Basin.
\end{abstract}

Keywords: Atlantic Forest, conservation, Euglossina, euglossine bees, Hexapoda.

\section{A fauna de abelhas-das-orquídeas (Hymenoptera: Apidae) do Parque Nacional do Monte Pascoal, do Parque Nacional do Descobrimento e de três outros remanescentes de Mata Atlântica no sul da Bahia, leste do Brasil}

\begin{abstract}
Resumo
As faunas de abelhas-das-orquídeas do Parque Nacional do Monte Pascoal, do Parque Nacional do Descobrimento e de três outros fragmentos de Mata Atlântica, com áreas de um a trezentos hectares, foram amostradas no sul da Bahia, leste do Brasil. Iscas com 17 diferentes fragrâncias atrativas a machos de abelhas-das-orquídeas foram utilizadas. Um total de 4.764 machos, pertencentes a 36 espécies, foram ativamente coletados com o auxílio de redes entomológicas durante 300 horas, entre novembro de 2008 e novembro de 2009. A riqueza e a diversidade de abelhas euglossinas encontradas no presente estudo são as mais altas já registradas em todo o domínio da Mata Atlântica. Eufriesea dentilabris (Mocsáry, 1897) e Eufriesea violacea (Blanchard, 1840) foram coletadas no Parque Nacional do Monte Pascoal, sendo estes os primeiros registros dessas espécies no Estado da Bahia e também o registro mais ao norte conhecido para ambas. Fêmeas de Exaerete dentata (Linnaeus, 1758) também foram coletadas no Parque Nacional do Monte Pascoal e antigos registros de Eufriesea aeneiventris (Mocsáry, 1896) neste sítio fazem deste Parque a área com a maior riqueza e a maior diversidade de abelhas euglossinas de toda a Mata Atlântica, mostrando-se similar a áreas da Bacia Amazônica.
\end{abstract}

Palavras-chave: Mata Atlântica, conservação, Euglossina, abelhas euglossinas, Hexapoda.

\section{Introduction}

Orchid bees (Hymenoptera: Apidae: Euglossina) are important pollinators in Neotropical forests (reviewed by Dressler, 1982a) and consequently key organisms in ecosystems where they live. These bees became a favourite in ecological studies (e.g. Nemésio and Silveira, 2006b, 2007a, 2010; Rasmussen, 2009; Abrahamczyk et al., 2011) due to the ease of collecting their males, which are heavily attracted to synthetic aromatic compounds that mimic natural floral fragrances (Vogel, 1966; Dodson et al., 1969).

Studies involving orchid bees in the Brazilian Atlantic Forest, one of the earth's biological "hotspots" (Myers, 1988; Mittermeier et al., 1999; Galindo-Leal and Câmara, 
2003), only began some twenty years after similar studies in Central America and in the Amazon Basin (e.g. Raw, 1989; Rebêlo and Garófalo, 1991, 1997). The region of the southern state of Bahia, the portion of the Atlantic Forest with the highest levels of endemism for many taxonomic groups (e.g., Dean, 1995; Pacheco et al., 1996; Thomas et al., 1997, 1998; Sambuichi et al., 2008; Laurance, 2009), has only very recently received attention to its orchid-bee fauna (Melo, 2005; Nemésio, 2011a, 2012b, 2013a, c; Nemésio et al., 2012).

Approximately 60 orchid-bee species are known from the Atlantic Forest (Nemésio and Silveira, 2007b; Nemésio, 2009), which makes its orchid-bee fauna the least rich of the three largest Neotropical forest biomes (see Nemésio and Silveira, 2007b). Nonetheless, the region of southern Bahia, also known as 'Hileia Baiana', has been shown to hold more than half of the entire Atlantic Forest orchid-bee richness, and some areas, such as the 'Reserva Biológica de Una', with ca. 30 species (Nemésio, 2013a), can hold almost as many species as several Amazonian sites. Recent studies in southern Bahia have also found some new species (Moure, 1996; Nemésio, 2011c, d, 2012a; Nemésio and Engel, 2012) and some species previously unknown to occur at the area (Nemésio 2011a, e).

Organisms endemic in severely deforested biomes, as happens to be the case with the Atlantic Forest, are more prone to population declines and even to extinction (Collinge, 1996; Tocher et al., 1997). Concerning orchid bees, it has been suggested that some species with restricted geographic distributions within the Atlantic Forest domain may be severely affected by their habitat loss (Nemésio, 2009, 2010a, b, 2011b; Faria Junior and Melo, 2011; Nemésio et al., 2012). Thus, despite recent samplings in southern Bahia, more surveys are still needed to correctly assess the orchid-bee fauna of this region and accurately establish the geographic distributions of its species. This goal could not be achieved if the largest forest remnants of Atlantic Forest in the region were not surveyed.

The main goal of this study, thus, is to provide distributional and taxonomic data on the orchid bees of southern Bahia by surveying the two largest forest preserves at this region, the national parks of Monte Pascoal (22,383 ha) and Descobrimento (21,213 ha), and three forest remnants of different sizes (ranging from 1 to $300 \mathrm{ha}$ ) situated between both parks, for their orchidbee faunas. Given the difference in size among the forest remnants, it was also tested how reduction in forest area affects richness and diversity of orchid bees.

\section{Material and Methods}

\subsection{Study sites}

This study was conducted in five forest remnants in the southern part of Bahia state: (i) 'Parque Nacional do Monte Pascoal' (PNMP), a 22,383-ha preserve situated in the municipality of Porto Seguro; (ii) 'Parque Nacional do Descobrimento' (PND), a 21,213-ha preserve situated in the municipality of Prado; and three forest patches situated in the municipality of Itamaraju, between Porto Seguro and Prado, with total areas of 1 ha (F1), 150 ha (F150) and 300 ha (F300) (see Figure 1). Most of PNMP still consists of pristine forest, since it is the oldest preserve in the region (established in 1961), but it has been severely impacted by the Pataxó Indians who invaded the area in 1999 and still live there, where they hunt (with fire guns) and cut down trees for wood; PND consists of secondary forests in various successional stages, since pastures and other crops happened to emerge in the area before the establishment of the preserve, in 1999, but pristine forested areas can also be found in the preserve, particularly at its northernmost and easternmost portions; F1 is a small forest area surrounded by a pasture matrix and only a few hundred metres from Itamaraju town, with strong anthropogenic pressures; F150 is a private area ('Fazenda Flor do Monte') surrounded by pastures and located some $20 \mathrm{~km}$ southwest of the PNMP; F300 is an area belonging to the Pataxó Indians who inhabit the region, also surrounded by pasture and other crops, about $10 \mathrm{~km}$ from PNMP and connected to other forest patches (Figure 1). The three forest patches F1, F150, and F300 consist mostly of secondary forests and are under severe anthropogenic impact. Collections were carried out from November, 2008 to November, 2009 at PNMP and F300, and from November, 2008 to January, 2009 at PND, F1 and F150. The vegetation of the region is essentially dense Atlantic Rain Forest [Central Lowland Forest according to Thomas and Carvalho (2003)]. Precipitation in the area is about 1,300 mm/year (Thomas and Carvalho, 2003).

\subsection{Sampling}

Twenty hours of active sampling with insect nets were performed in each of the selected sites in the areas. Collections were carried out at any time from 07:00h to $17: 00 \mathrm{~h}$, in consecutive or non-consecutive days until 20 hours of collection were reached. Usually, it took two to three days to sample each site for 20 hours, but due to meteorological conditions, more than three days were necessary for some sites. Three sites were sampled at both PNMP and PND, and one site at F1, F150 and F300. At PNMP each site was sampled twice (once during the rainy season and once during the drier season) and at F300 the single site was sampled four times (twice during the rainy season, once at the beginning of the drier season and once at the end of the drier season), totalling 300 hours, following the methodology proposed by Nemésio (2010a, b, 2011a, b): PNMP site-1 (16 53' 07' S and 39 24' 47' W, ca. 136 $\mathrm{m}$ a.s.1.), PNMP site-2 (16 $52^{\prime}$ '57' $\mathrm{S}$ and $39^{\circ} 24^{\prime} 39^{\prime \prime} \mathrm{W}$, ca. $100 \mathrm{~m}$ a.s.1.), and PNMP site-3 (16 $52^{\prime} 41^{\prime \prime} \mathrm{S}$ and $39^{\circ}$ 24 ' 56 " W, ca. $60 \mathrm{~m}$ a.s.l.) were sampled from November, 2008 to January, 2009, and again in April, October and November, 2009; PND site-1 (17 $07^{\circ}$ ' $40^{\prime \prime}$ S and $39^{\circ} 19^{\prime}$ $11^{\prime \prime} \mathrm{W}$, ca. $50 \mathrm{~m}$ a.s.1.) and PND site- 2 were sampled in late December, 2008; PND site-3 (17 ${ }^{\circ} 06^{\prime} 12^{\prime}$ ' $\mathrm{S}$ and $39^{\circ}$ $17^{\prime} 01^{\prime \prime} \mathrm{W}$, ca. $80 \mathrm{~m}$ a.s.l.) was sampled in early January, 2009; F1 (17 01 ' 25 'S and $39^{\circ} 31^{\prime}$ '34" W, ca. $30 \mathrm{~m}$ a.s.1.) was sampled from late November to early December, 2008; F150 (16 59' 57' S and 39 33' 21' W, ca. $100 \mathrm{~m}$ a.s.1.) was sampled from late December, 2008, to early January, 2009; F300 (16 54' 51' S and 39 31' 17' 'W, ca. $25 \mathrm{~m}$ a.s.1.) was sampled twice from late November, 2008 to mid-January, 2009, then in April, 2009 and again in early 


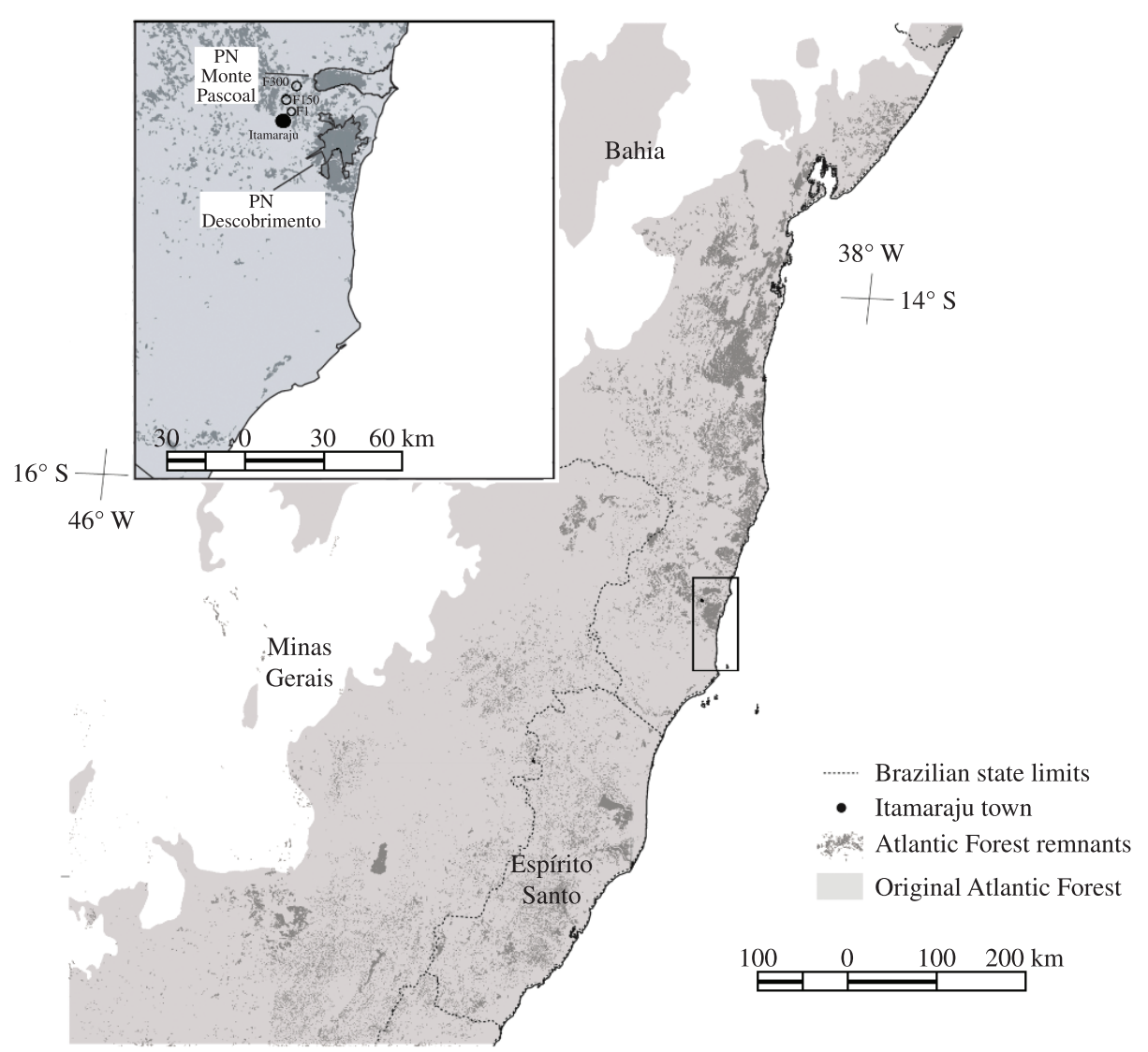

Figure 1. Map of southern state of Bahia showing the location of the five areas sampled in this study.

October and early November, 2009. At PNMP, sites 1 and 3 were located in areas with pristine, well developed forest, whereas site 2, for comparison, was located in an area in early to intermediate successional stage, close to the edge. At PND, sites 1 and 2 were located in areas with pristine forest, whereas site 3 was located in an area in early to intermediate successional stage. At each site, 17 scent baits were placed $c a$. 2.0 metres apart from each other at about $1.5 \mathrm{~m}$ above the ground. These baits were made of cotton wadding soaked with one of the following substances, known or believed to be attractive to orchid bees: benzyl acetate, benzyl alcohol, $r$-carvone, 1,8-cineole, $p$-cresol acetate, dimethoxybenzene, eugenol, $\beta$-ionone, methyl benzoate, methyl trans-cinnamate, heneicosane, methyl salicylate, skatole, tricosane, $p$-tolyl acetate, vanillin, and a mixture $(1: 1)$ of methyl trans-cinnamate and $p$-tolyl acetate. Baits with cineole, the most volatile compound, were recharged every hour. Bees arriving on the baits during the sampling period were collected with insect nets and killed with ethyl acetate. They were pinned and labelled as belonging to the project 'Euglossina da Hileia Baiana' and deposited at the Entomological Collection of the 'Universidade Federal de Minas Gerais' (UFMG).

\subsection{Data analysis}

Diversity was estimated through the Shannon-Wiener diversity index $\left(H^{\prime}\right)$, as $H^{\prime}=-\Sigma p_{i} \ln \left(p_{i}\right)$, where $p_{i}$ is the proportion of total number of species made up of the ith species (Pielou, 1975). Evenness (E) was estimated through the formula $E=H^{\prime} / \ln (S)$, where $S$ is the species richness. Spearman rank correlation tests were used to estimate the effect of forest size (area in ha) on bee richness and diversity (sites within each area were grouped together). The similarity in faunistic composition among all five areas (sites within each area were combined together) was estimated by the percent similarity index of Renkonen, recommended by Wolda (1981) for small samples and strongly recommended by Balmer (2002) since it deals with relative abundances of species. Based on those similarities, the areas were grouped using UPGMA (Sneath and Sokal, 1973).

\subsection{Taxonomy}

Taxonomy follows Nemésio and Rasmussen (2011) with the additions provided by Hinojosa-Díaz et al. (2012), Nemésio (2012a) and Nemésio and Engel (2012).

\section{Results}

Four thousand seven hundred and sixty-four males belonging to 36 species were collected in all five areas (Tables 1-4). All 36 species were collected at 'Parque Nacional do Monte Pascoal' (Table 1), whereas the other four forest areas (smaller than PNMP) presented subsets 
of PNMP's fauna in decreasing order according to their area: 29 species were collected at PND (the second largest area) (Table 2), 26 at F300 (Table 3), 22 at F150 and only seven species were collected at F1 (Table 4). Similar trends were observed when diversity and evenness are considered: diversity ranged from $\mathrm{H}^{\prime}=0.57(\mathrm{~F} 1$, the smallest area) to $\mathrm{H}^{\prime}=2.62$ (PNMP, the largest area), and evenness ranged from $\mathrm{E}=0.29(\mathrm{~F} 1)$ to $\mathrm{E}=0.79(\mathrm{~F} 300)$

Table 1. Diversity, evenness, species richness and number of specimens of each orchid-bee species collected at sites 1 to 3 at the 'Parque Nacional do Monte Pascoal', state of Bahia, eastern Brazil, in rainy and dry seasons after 20 hours of sampling in each site.

\begin{tabular}{|c|c|c|c|c|c|c|c|}
\hline \multirow{2}{*}{ Species } & \multicolumn{3}{|c|}{ Rainy season } & \multicolumn{3}{|c|}{ Dry season } & \multirow{2}{*}{ Total } \\
\hline & Site 1 & Site 2 & Site 3 & Site 1 & Site 2 & Site 3 & \\
\hline Eufriesea atlantica Nemésio, 2008 & 00 & 01 & 00 & 00 & 00 & 00 & 01 \\
\hline Eufriesea dentilabris (Mocsáry, 1897) & 01 & 00 & 00 & 00 & 00 & 00 & 01 \\
\hline Eufriesea surinamensis (Linnaeus, 1758) & 01 & 04 & 00 & 00 & 00 & 01 & 06 \\
\hline Eufriesea violacea (Blanchard, 1840) & 01 & 00 & 00 & 00 & 00 & 01 & 02 \\
\hline Euglossa amazonica Dressler, 1982b & 00 & 01 & 02 & 00 & 00 & 01 & 04 \\
\hline Euglossa aratingae Nemésio, 2009 & 00 & 00 & 01 & 00 & 00 & 00 & 01 \\
\hline $\begin{array}{l}\text { Euglossa augaspula Hinojosa-Díaz, Nemésio \& } \\
\text { Engel, } 2012\end{array}$ & 00 & 01 & 31 & 01 & 05 & 01 & 39 \\
\hline Euglossa avicula Dressler, 1982 & 00 & 13 & 08 & 03 & 02 & 01 & 27 \\
\hline Euglossa bembei Nemésio, 2011d & 00 & 02 & 03 & 00 & 00 & 00 & 05 \\
\hline Euglossa carolina Nemésio, 2009 & 07 & 103 & 179 & 04 & 88 & 60 & 441 \\
\hline Euglossa clausi Nemésio and Engel, 2012 & 02 & 18 & 37 & 00 & 05 & 03 & 65 \\
\hline Euglossa cognata Moure, 1970 & 01 & 09 & 39 & 07 & 04 & 15 & 75 \\
\hline Euglossa cyanochlora Moure, 1996 & 00 & 00 & 00 & 00 & $02 *$ & 00 & 02 \\
\hline Euglossa despecta Moure, 1968 & 02 & 04 & 32 & 12 & 35 & 18 & 103 \\
\hline Euglossa fimbriata Moure, 1968 & 04 & 09 & 18 & 00 & 00 & 01 & 32 \\
\hline Euglossa hemichlora Cockerell, 1917 & 00 & 00 & 04 & 00 & 00 & 00 & 04 \\
\hline Euglossa ignita Smith, 1874 & 19 & 24 & 129 & 19 & 54 & 92 & 337 \\
\hline Euglossa imperialis Cockerell, 1922 & 32 & 39 & 63 & 43 & 83 & 99 & 359 \\
\hline Euglossa leucotricha Rebêlo and Moure, 1996 & 00 & 03 & 00 & 00 & 00 & 00 & 03 \\
\hline Euglossa liopoda Dressler, 1982 & 00 & 00 & 02 & 00 & 00 & 00 & 02 \\
\hline Euglossa marianae Nemésio, 2011b & 02 & 05 & 36 & 03 & 13 & 10 & 69 \\
\hline Euglossa milenae Bembé, 2007 & 01 & 02 & 01 & 00 & 01 & 00 & 05 \\
\hline Euglossa mixta Friese, 1899 & 01 & 06 & 28 & 05 & 13 & 17 & 70 \\
\hline Euglossa monnei Nemésio, 2012a & 00 & 00 & 01 & 00 & 00 & 01 & 02 \\
\hline Euglossa pepei Nemésio and Engel, 2012 & 00 & 00 & 01 & 00 & 00 & 01 & 02 \\
\hline Euglossa pleosticta Dressler, 1982 & 01 & 10 & 09 & 01 & 02 & 02 & 25 \\
\hline Euglossa roubiki Nemésio, 2009 & 54 & 46 & 72 & 09 & 33 & 37 & 251 \\
\hline Euglossa securigera Dressler, 1982 & 00 & 12 & 26 & 00 & 00 & 00 & 38 \\
\hline Euglossa viridis (Perty, 1833) & 00 & 00 & 01 & 00 & 00 & 01 & 02 \\
\hline Eulaema atleticana Nemésio, 2009 & 03 & 14 & 29 & 00 & 06 & 04 & 56 \\
\hline Eulaema marcii Nemésio, 2009 & 33 & 27 & 29 & 09 & 10 & 22 & 130 \\
\hline Eulaema nigrita Lepeletier, 1841 & 07 & 48 & 67 & 08 & 27 & 13 & 170 \\
\hline Eulaema niveofasciata (Friese, 1899) & 11 & 13 & 20 & 07 & 04 & 12 & 67 \\
\hline Exaerete frontalis (Guérin-Méneville, 1844) & 03 & 04 & 02 & 01 & 00 & 01 & 11 \\
\hline Exaerete salsai Nemésio, 2011c & 00 & 01 & 00 & 00 & 00 & 00 & 01 \\
\hline Exaerete smaragdina (Guérin-Méneville, 1844) & 01 & 01 & 00 & 00 & 00 & 00 & 02 \\
\hline Total & 187 & 420 & 870 & 132 & 387 & 414 & 2,410 \\
\hline Species richness $(\mathrm{S})$ & 21 & 27 & 28 & 15 & 18 & 24 & 36 \\
\hline Shannon-Wiener diversity index (H') & 2.20 & 2.62 & 2.67 & 2.22 & 2.25 & 2.27 & 2.62 \\
\hline Evenness (E) & 0.72 & 0.79 & 0.80 & 0.82 & 0.78 & 0.71 & 0.73 \\
\hline
\end{tabular}


Table 2. Diversity, evenness, species richness and number of specimens of each orchid-bee species collected at sites 1 to 3 at the 'Parque Nacional do Descobrimento', state of Bahia, eastern Brazil, after 20 hours of sampling in each site.

\begin{tabular}{|c|c|c|c|c|}
\hline Species & Site 1 & Site 2 & Site 3 & Total \\
\hline Eufriesea atlantica Nemésio, 2008 & 00 & 00 & 01 & 01 \\
\hline Eufriesea surinamensis (Linnaeus, 1758) & 00 & 00 & 01 & 01 \\
\hline Euglossa amazonica Dressler, 1982b & 00 & 05 & 06 & 11 \\
\hline Euglossa augaspula Hinojosa-Díaz, Nemésio \& Engel, 2012 & 00 & 01 & 03 & 04 \\
\hline Euglossa avicula Dressler, 1982b & 02 & 00 & 02 & 04 \\
\hline Euglossa bembei Nemésio, 2011 & 00 & 01 & 00 & 01 \\
\hline Euglossa carolina Nemésio, 2009 & 37 & 132 & 220 & 389 \\
\hline Euglossa clausi Nemésio and Engel, 2012 & 02 & 13 & 11 & 26 \\
\hline Euglossa cognata Moure, 1970 & 02 & 10 & 04 & 16 \\
\hline Euglossa despecta Moure, 1968 & 00 & 10 & 13 & 23 \\
\hline Euglossa fimbriata Moure, 1968 & 10 & 03 & 05 & 18 \\
\hline Euglossa ignita Smith, 1874 & 14 & 30 & 07 & 51 \\
\hline Euglossa imperialis Cockerell, 1922 & 21 & 19 & 13 & 53 \\
\hline Euglossa liopoda Dressler, 1982b & 00 & 00 & 02 & 02 \\
\hline Euglossa marianae Nemésio, 2011b & 03 & 07 & 04 & 14 \\
\hline Euglossa milenae Bembé, 2007 & 00 & 02 & 00 & 02 \\
\hline Euglossa mixta Friese, 1899 & 05 & 21 & 59 & 85 \\
\hline Euglossa monnei Nemésio, 2012 & 01 & 01 & 00 & 02 \\
\hline Euglossa pepei Nemésio and Engel, 2012 & 01 & 00 & 00 & 01 \\
\hline Euglossa pleosticta Dressler, 1982b & 01 & 03 & 01 & 05 \\
\hline Euglossa roubiki Nemésio, 2009 & 38 & 16 & 14 & 68 \\
\hline Euglossa securigera Dressler, 1982b & 01 & 01 & 03 & 05 \\
\hline Eulaema atleticana Nemésio, 2009 & 11 & 08 & 18 & 37 \\
\hline Eulaema marcii Nemésio, 2009 & 10 & 05 & 13 & 28 \\
\hline Eulaema nigrita Lepeletier, 1841 & 04 & 28 & 36 & 68 \\
\hline Eulaema niveofasciata (Friese, 1899) & 06 & 09 & 06 & 21 \\
\hline Exaerete frontalis (Guérin-Méneville, 1844) & 03 & 01 & 10 & 14 \\
\hline Exaerete salsai Nemésio, 2011 & 00 & 00 & 01 & 01 \\
\hline Exaerete smaragdina (Guérin-Méneville, 1844) & 01 & 07 & 05 & 13 \\
\hline Total & 173 & 333 & 458 & 964 \\
\hline Species richness $(\mathrm{S})$ & 20 & 23 & 25 & 29 \\
\hline Shannon-Wiener diversity index (H') & 2.38 & 2.29 & 2.05 & 2.32 \\
\hline Evenness (E) & 0.79 & 0.73 & 0.64 & 0.69 \\
\hline
\end{tabular}

(Tables 1-4). PNMP also presented the highest abundance (ca. 20 specimens/hour), followed by PND and F150 (ca. 16 specimens/hour), F1 (ca. 12 specimens/hour) and F300 (ca. 10 specimens/hour).

Euglossa carolina Nemésio, 2009 was the most common species in all sampled areas, but its dominance ranged from $87 \%$ at F1 to only $18 \%$ and $14 \%$ at PNMP and F300 respectively (Tables 1-4). Euglossa ignita Smith, 1874, Eg. imperialis Cockerell, 1922 and Eg. roubiki Nemésio, 2009, three species belonging to the subgenus Glossura Cockerell, 1917, were also common species in four of the five areas (except F1), and at F300 Eg. ignita was the dominant species (Table 3).

A marked difference was found between the two areas where samplings were carried out during the rainy and drier seasons: at PNMP abundance was about 50\% higher during the rainy season, whereas at F300 there was no difference in abundance. Populations of some species, however, seemed to fluctuate between seasons (Tables 1 and 3).

There were significant correlations between forest remnant size and richness $\left(r_{s}=1.00, \mathrm{P}<0.05\right)$ and diversity $\left(r_{s}=0.90, P<0.05\right)$. The ordination of the sites according to their faunas showed a great overall similarity among the three largest forest areas and a decrease in similarity between these three areas and the two smallest areas. PNMP and the nearby F300 grouped together with ca. $81 \%$ similarity and then grouped to PND with ca. $65 \%$ similarity. These three areas grouped with F150 with ca. $56 \%$ similarity and, then, all four areas grouped with F1with only ca. $35 \%$ similarity (Figure 2). 
Table 3. Diversity, evenness, species richness and number of specimens of each orchid-bee species collected at a 300-ha forest remnant in the municipality of Itamaraju, state of Bahia, eastern Brazil. Bees were collected during 20 hours in each sampling. Two samplings were performed during the rainy season and two samplings in the drier season (see Material and Methods for further details).

\begin{tabular}{|c|c|c|c|c|c|}
\hline \multirow{2}{*}{ Species } & \multicolumn{2}{|c|}{ Rainy season } & \multicolumn{2}{|c|}{ Dry season } & \multirow{2}{*}{ Total } \\
\hline & Sampling 1 & Sampling 2 & Sampling 1 & Sampling 2 & \\
\hline Eufriesea atlantica Nemésio, 2008 & 05 & 00 & 00 & 02 & 07 \\
\hline Eufriesea surinamensis (Linnaeus, 1758) & 08 & 00 & 00 & 06 & 14 \\
\hline Euglossa amazonica Dressler, 1982b & 02 & 04 & 00 & 03 & 09 \\
\hline Euglossa aratingae Nemésio, 2009 & 01 & 00 & 00 & 00 & 01 \\
\hline $\begin{array}{l}\text { Euglossa augaspula Hinojosa-Díaz, Nemésio } \\
\text { \& Engel, } 2012\end{array}$ & 02 & 03 & 01 & 07 & 13 \\
\hline Euglossa avicula Dressler, $1982 \mathrm{~b}$ & 00 & 02 & 00 & 00 & 02 \\
\hline Euglossa carolina Nemésio, 2009 & 38 & 18 & 15 & 44 & 115 \\
\hline Euglossa clausi Nemésio and Engel, 2012 & 12 & 23 & 04 & 32 & 71 \\
\hline Euglossa cognata Moure, 1970 & 00 & 00 & 00 & 02 & 02 \\
\hline Euglossa cyanochlora Moure, 1996 & 00 & 03 & 00 & 04 & 07 \\
\hline Euglossa despecta Moure, 1968 & 03 & 03 & 00 & 10 & 16 \\
\hline Euglossa fimbriata Moure, 1968 & 03 & 00 & 00 & 08 & 11 \\
\hline Euglossa ignita Smith, 1874 & 22 & 51 & 46 & 43 & 162 \\
\hline Euglossa imperialis Cockerell, 1922 & 09 & 17 & 09 & 09 & 44 \\
\hline Euglossa milenae Bembé, 2007 & 01 & 01 & 00 & 01 & 03 \\
\hline Euglossa mixta Friese, 1899 & 02 & 03 & 00 & 03 & 08 \\
\hline Euglossa monnei Nemésio, 2012 & 00 & 00 & 01 & 01 & 02 \\
\hline Euglossa pleosticta Dressler, 1982b & 02 & 04 & & 05 & 11 \\
\hline Euglossa roubiki Nemésio, 2009 & 20 & 32 & 04 & 13 & 69 \\
\hline Euglossa securigera Dressler, 1982b & 05 & 08 & 00 & 15 & 28 \\
\hline Eulaema atleticana Nemésio, 2009 & 04 & 09 & 03 & 06 & 22 \\
\hline Eulaema marcii Nemésio, 2009 & 25 & 35 & 27 & 16 & 103 \\
\hline Eulaema nigrita Lepeletier, 1841 & 18 & 34 & 04 & 22 & 78 \\
\hline Eulaema niveofasciata (Friese, 1899) & 03 & 08 & 03 & 01 & 15 \\
\hline Exaerete frontalis (Guérin-Méneville, 1844) & 01 & 00 & 02 & 00 & 03 \\
\hline Exaerete smaragdina (Guérin-Méneville, 1844) & 02 & 04 & 04 & 03 & 13 \\
\hline Total & 188 & 262 & 123 & 256 & 829 \\
\hline Species richness (S) & 22 & 19 & 13 & 23 & 26 \\
\hline Shannon-Wiener diversity index (H') & 2.56 & 2.47 & 1.92 & 2.63 & 2.59 \\
\hline Evenness (E) & 0.83 & 0.84 & 0.75 & 0.84 & 0.79 \\
\hline
\end{tabular}

\section{Discussion}

\subsection{Faunistics, richness and diversity}

The strategy of intensive sampling, using the same methods as employed here, over a few days during the season when orchid bees are most actively foraging, has been demonstrated to be adequate for surveys focusing on this group of bees (Nemésio 2010b, 2011a, b, Nemésio et al. 2012). In the present study it was also shown that species richness can also be adequately recorded through this methodology during the drier season as well. Nevertheless, it should be stressed that at the particular region where these samplings were performed, there is no well-defined "dry" season and precipitation is usually high even during the driest months. Thus, this methodology should be used in other areas with well-defined dry seasons with great care during the drier seasons.

Neves and Viana (2003) listed 33 species for the Atlantic Forest of Bahia, but Nemésio (2009, 2011a) showed that some of them are junior synonyms of other species found in the area and other species were misidentifications. Nemésio (2011a) recognised 26 species occurring in southern Bahia from Uruçuca, in the north, to Porto Seguro, in the south. This figure was raised to 29 species after the survey at 'Reserva Biológica de Una' (Nemésio, 2013a). Seven species are here added to this list: Eufriesea dentilabris (Mocsáry, 1897), Ef. violacea (Blanchard, 1840), Euglossa aratingae Nemésio, 2009, Eg. hemichlora Cockerell, 1917, Eg. leucotricha Rebêlo and Moure, 1996, Eg. pepei 
Table 4. Diversity, evenness, species richness and number of specimens of each orchid-bee species collected at two forest fragments in the municipality of Itamaraju, state of Bahia, eastern Brazil, after 20 hours of sampling in each site. $\mathrm{F} 1=1$-ha forest remnant; $\mathrm{F} 150=150$-ha forest remnant (see Material and Methods for further details).

\begin{tabular}{lcc}
\hline \multicolumn{1}{c}{ Species } & F1 & F150 \\
\hline Eufriesea atlantica Nemésio, 2008 & 00 & 01 \\
Eufriesea surinamensis (Linnaeus, 1758) & 00 & 01 \\
Euglossa amazonica Dressler, 1982b & 00 & 03 \\
Euglossa augaspula Hinojosa-Díaz, & 00 & 04 \\
Nemésio \& Engel, 2012 & & \\
Euglossa bembei Nemésio, 2011 & 00 & 01 \\
Euglossa carolina Nemésio, 2009 & 206 & 107 \\
Euglossa clausi Nemésio and Engel, 2012 & 01 & 35 \\
Euglossa cognata Moure, 1970 & 00 & 01 \\
Euglossa cyanochlora Moure, 1996 & 00 & 01 \\
Euglossa despecta Moure, 1968 & 02 & 04 \\
Euglossa fimbriata Moure, 1968 & 00 & 05 \\
Euglossa ignita Smith, 1874 & 06 & 27 \\
Euglossa imperialis Cockerell, 1922 & 00 & 03 \\
Euglossa milenae Bembé, 2007 & 00 & 02 \\
Euglossa pleosticta Dressler, 1982b & 00 & 06 \\
Euglossa roubiki Nemésio, 2009 & 00 & 09 \\
Euglossa securigera Dressler, 1982b & 08 & 01 \\
Eulaema atleticana Nemésio, 2009 & 00 & 02 \\
Eulaema marcii Nemésio, 2009 & 00 & 05 \\
Eulaema nigrita Lepeletier, 1841 & 13 & 86 \\
Exaerete frontalis (Guérin-Méneville, & 00 & 01 \\
1844) & & \\
Exaerete smaragdina (Guérin-Méneville, & 01 & 19 \\
1844) & & \\
Total & $\mathbf{2 3 7}$ & $\mathbf{3 2 4}$ \\
Species richness (S) & 07 & 22 \\
Shannon-Wiener diversity index (H') & 0.57 & 2.02 \\
Evenness (E) & 0.29 & 0.65 \\
\hline & &
\end{tabular}

Nemésio and Engel, 2012, and Exaerete salsai Nemésio, 2011c. The species considered as Eg. crassipunctata Moure, 1968 in all previous studies in the Atlantic Forest is here treated as Eg. clausi Nemésio and Engel, 2012. This is the northernmost record of both Ef. dentilabris and Ef. violace a and the first published record of these species for the state of Bahia (in fact, R. L. Dressler had already collected Ef. violacea exactly at the 'Monte Pascoal' region in 1968; data from his field notes available at ftp:// ftp.flmnh.ufl.edu/Public/Dressler/).

Females of the cleptoparasitic Exaerete dentata (Linnaeus, 1758) were also collected in the present study when searching for nests of Eufriesea surinamensis (Linnaeus, 1758) at PNMP, its most common host. Males of this species are usually not attracted to the synthetic scents used in orchid-bee inventories (see Nemésio and Silveira, 2006a) and, thus, were not recorded during regular

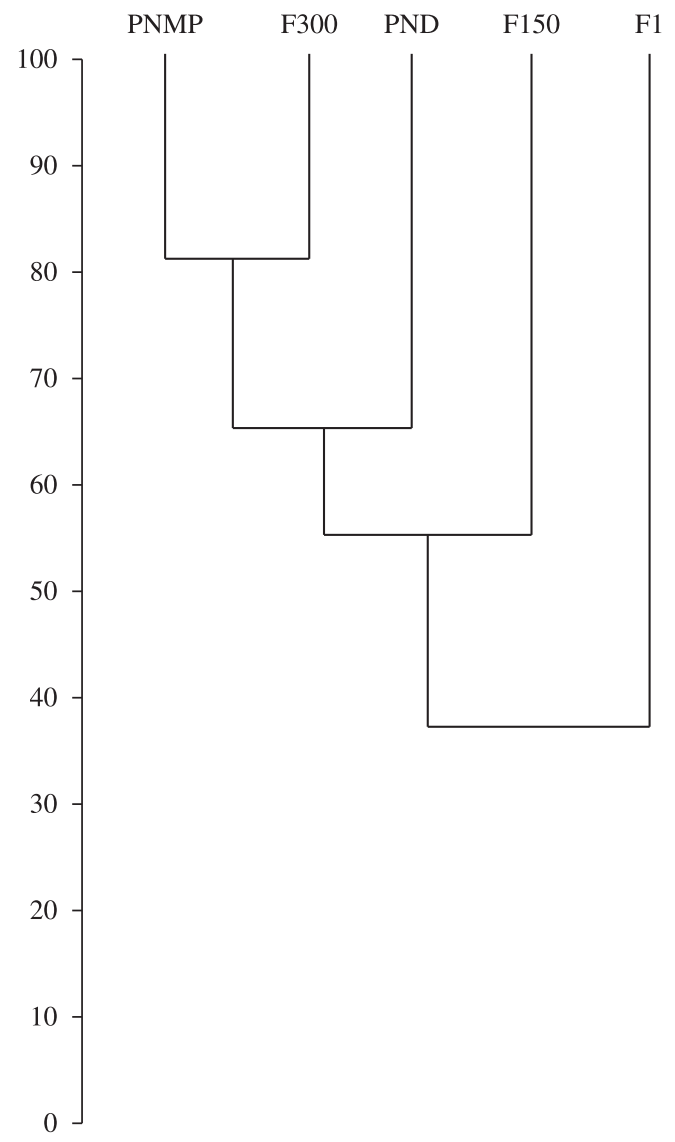

Figure 2. Clustering of the five areas at the 'Monte Pascoal' region according to the similarity of their orchid bee faunas. PNMP = 'Parque Nacional do Monte Pascoal', Porto Seguro, Bahia; PND = 'Parque Nacional do Descobrimento', Prado, Bahia; F1 = forest fragment of 1 ha, Itamaraju, Bahia; F150 = 'Fazenda Flor do Monte', a 150-ha forest fragment, Itamaraju; F300 = forest fragment of 300 ha, Itamaraju.

samplings. Sixteen specimens of Eufriesea aeneiventris (Mocsáry, 1896) were collected in Itamaraju and in the neighbourhood of PNMP in October and November, 1985 [specimens deposited at 'Museu Nacional' (Rio de Janeiro) and UFMG], but were not collected in the present study. Euglossa carinilabris Dressler, 1982b was collected in Ilhéus and Itabuna, in the state of Bahia (Dressler, 1982b; Nemésio, in prep.), and in Santa Teresa, in the state of Espírito Santo (Faria Junior and Melo, 2007) and the present study area is exactly between both sites, suggesting it may occur in the region. Euglossa stellfeldi Moure, 1947 and Euglossa truncata Rebêlo and Moure, 1996, are known to occur in high elevations (above $800 \mathrm{~m}$ a.s.1.) at the border of the states of Minas Gerais and Bahia (Nemésio, 2012b), only some $50 \mathrm{~km}$ from PNMP, and Eg. stellfeldi reaches the mountains in the region of Camacan, near 'Reserva Biológica de Una' (Nemésio, in prep.). Finally, Eulaema seabrai Moure, 1960, another species usually not attracted to the synthetic scents used in orchid bee surveys (Nemésio and Silveira, 2004, 2006b), is known to occur in southern Bahia (Oliveira, 2008). These seven species 
raise the number of orchid-bee species known to occur in southern Bahia to 42 - and 38 of them (including Ex. dentata, recorded in the present study, and Ef. aeneiventris) are known to occur sympatrically at PNMP, what makes this single area the richest and most diverse Atlantic Forest site concerning its orchid-bee fauna, far beyond 'Reserva Natural Vale' in Linhares, state of Espírito Santo, with 31 species (Bonilla-Gómez, 1999), PND, with 29 species (this study), and 'Reserva Biológica de Una', also with 29 species (Nemésio, 2013a). This figure of 38 species is only rivalled by Amazonian (e.g. Pearson and Dressler, 1985; Oliveira and Campos, 1996) and Central American (e.g. Ackerman, 1989) sites but it is still superior to many sites in the Brazilian (e.g. Nemésio and Morato, 2006; StorckTonon et al., 2009, 2011) and Peruvian (e.g. Rasmussen, 2009) Amazon. Although the entire Atlantic Forest domain is not especially rich in orchid-bee species when compared to the Amazon and Central American forests (see Nemésio and Silveira, 2007b), 'Parque Nacional do Monte Pascoal' presents an astonishingly rich and diverse orchid-bee fauna, comparable to the richest sites in the Neotropics.

Nowhere in the Atlantic Forest domain the effect of fragmentation, with its consequent reductions in size of remaining forest patches, is more obvious than at the 'Monte Pascoal' region. Previous studies (Bezerra and Martins, 2001; Nemésio and Silveira, 2007a, 2010) had suggested that reduction of the original forested areas could lead to a decrease in richness and diversity of orchid-bee faunas. Nevertheless, the absence of large, well preserved forest remnants in the same micro-regions that could be used as a "control" area in the aforementioned studies (i.e., an area large enough to still hold the full pool of the original species occurring in the region) made it difficult to conclude whether the observed patterns were a consequence of deforestation or a natural feature of the local orchid-bee faunas. The present data show unequivocally that reduction in size does affect not only richness, but also diversity, since few or usually one dominant species tend to respond for the majority of specimens found in these smaller areas. Euglossa carolina, a species typical of disturbed areas, tended to be more and more common towards the smaller forest remnants or, alternatively, those with disturbed vegetation, as happens to be the case at PND, where most of the area consists of forests in early to intermediate successional stages.

Due especially to the fluctuations in the relative abundances of Euglossa carolina among the different areas, similarity among them were intermediate to high, except the two smallest forest patches. Species of Euglossa Latreille, 1802 belonging to the subgenus Glossura were also key species to group the areas, since they are an important component of the local orchid-bee community.

Euglossa marianae Nemésio, 2011b, a species considered to only occur in the largest and best preserved patches of the Atlantic Forest (see Tonhasca Junior et al., 2002; Nemésio and Silveira, 2006c; Nemésio 2011b, 2013b - treated as Eg. analis Westwood, 1840 in the two former studies), was only recorded within PNMP and PND. Its absence from F300, an area close to PNMP, reinforces the view that Eg. marianae is actually very sensitive to environmental disturbances.

\subsection{Conservation}

Similar to many other "protected" natural areas in eastern Brazil, the situation faced by the areas here sampled is problematic (few personnel to patrol the areas; presence of hunters and wood dealers; legal problems with former owners of the land; invasion by self-declared Indians who claim the area). The most dramatic situation is that of 'Parque Nacional do Monte Pascoal', illegally occupied by self-declared Pataxó Indians who claim possession of the area. The self-declared Indians currently live around the preserve with a population of about 15,000 people. They hunt in the area with fire guns (pers. obs.), cut down trees with electric saws (pers. obs.) to sell in the region or to build handicrafts intended to be sold to tourists at the nearby famous beaches. A large part of PNMP was already deforested and its original area of more than 22,000 ha is currently covered by no more than 10,000 ha of forest. On the other hand, the remaining forest at PNMP still consists of mature trees and this mature forest still holds an impressive richness and diversity of animals, orchid bees included. Urgent measures must be taken to protect this area and restore the 'de facto' governmental control of the area. A similar fate may be soon faced by PND, since self-declared Indians have tried (and some have succeeded) to occupy and get themselves established in the area. The same negative impacts reported for PNMP also happens at PND. The presence of apparently sensitive orchid-bee species, such as Euglossa marianae, Eg. roubiki, Eg. amazonica Dressler, 1982 (see Nemésio, 2010b, 2011b), and Eg. cyanochlora Moure, 1996, and rare species only recently described, such as Euglossa pepei and Exaerete salsai, suggests that these are key areas to preserve the impressive diversity of orchid bees of the region, with many endemic species. Nevertheless, if the conservation problems listed above are not urgently solved, there will probably be nothing left, due to the accelerated damage caused to the area by local people, self-declared Indians included, and the very slow governmental response to this situation.

Acknowledgements - The Brazilian government, through the environmental departments IBAMA and ICMBio, provided the collecting permit (\#18138-1). Jorge Nascimento (Julião) (ICMBio, Brasília), was very helpful in solving all problems concerning the above licence. The following people (institutions in parentheses) were kind enough to facilitate my access to all sampled areas: Magda Barros ('Parque Nacional do Monte Pascoal', Porto Seguro, Bahia), Eurípedes Pontes Júnior, Vicente Faria and Carlão ('Parque Nacional do Descobrimento', Prado, Bahia), Zezito Ferreira Santos (Funai-Itamaraju), Cacique Oziel Braga ('Aldeia Pé do Monte', 'Parque Nacional do Monte Pascoal'), José Roberto Santos ('Fazenda Flor do Monte', Itamaraju, Bahia), Guido Caliman and João Ademir Caliman ('Fazenda Guaíra', Prado, Bahia).

\section{References}

ABRAHAMCZYK, S., GOTTLEUBER, P., MATAUSCHEK, C. and KESSLER, M., 2011. Diversity and community composition of euglossine bee assemblages (Hymenoptera: Apidae) in western Amazonia. Biodiversity Conservation, vol. 20, p. 2981-3001. http://dx.doi.org/10.1007/s10531-011-0105-1 
ACKERMAN, JD., 1989. Geographic and seasonal variation in fragrance choices and preferences of male euglossine bees. Biotropica, vol. 21, p. 340-347. http://dx.doi.org/10.2307/2388284

BALMER, O., 2002. Species lists in ecology and conservation: abundances matter. Conservation Biology, vol. 16, p. 1160-1161. http://dx.doi.org/10.1046/j.1523-1739.2002.01568.x

BEZERRA, CP. and MARTINS, CF., 2001. Diversidade de Euglossinae (Hymenoptera, Apidae) em dois fragmentos de Mata Atlântica localizados na região urbana de João Pesssoa, Paraíba, Brasil. Revista Brasileira de Zoologia, vol. 18, p. 823-835. http:// dx.doi.org/10.1590/S0101-81752001000300018

BONILLA-GÓMEZ, MA., 1999. Caracterização da Estrutura Espaço-temporal da Comunidade de Abelhas Euglossinas (Hymenoptera, Apidae) na Hiléia Bahiana. Campinas: Universidade Estadual de Campinas. 153p. Unpublished Ph. D. Dissertation.

COLLINGE, SK., 1996. Ecological consequences of habitat fragmentation: implications for landscape architecture and planning. Landscape Urban Planning, vol. 36, p. 59-77. http:// dx.doi.org/10.1016/S0169-2046(96)00341-6

DEAN, W., 1995. With Broadax and Firebrand - The Destruction of the Brasilian Atlantic Forest. Berkeley: University of California Press.

DODSON, CH., DRESSLER, RL., HILLS, HG., ADAMS, RM. and WILLIAMS, NH., 1969. Biologically active compounds in orchid fragrances. Science, vol. 164, p. 1243-1249. http://dx.doi. org/10.1126/science.164.3885.1243

DRESSLER, RL., 1982a. Biology of the orchid bees (Euglossini). Annual Review of Ecology and Systematics, vol. 13, p. 373-394. http://dx.doi.org/10.1146/annurev.es.13.110182.002105

-, 1982b. New species of Euglossa. III. The bursigera species group (Hymenoptera: Apidae). Revista de Biologia Tropical, vol. 30, p. 131-140.

FARIA JUNIOR, LRR. and MELO, GAR., 2007. Species of Euglossa (Glossura) in the Brazilian Atlantic forest, with taxonomic notes on Euglossa stellfeldi Moure (Hymenoptera, Apidae, Euglossina). Revista Brasileira de Entomologia, vol. 51, p. 275-284.

-, 2011. A new species of Eufriesea Cockerell (Hymenoptera, Apidae, Euglossina) from northeastern Brazil. Revista Brasileira de Entomologia, vol. 55, p. 35-39. http://dx.doi.org/10.1590/ S0085-56262011000100007

GALINDO-LEAL, C. and CÂMARA, IG., 2003. Atlantic Forest hostpot status: an overview. In GALINDO-LEAL, C. and CÂMARA, IG. (Eds.). The Atlantic Forest of South America - biodiversity status, threats, and outlook. Washington: Island Press. p. 3-11.

HINOJOSA-DÍAZ, IA., NEMÉSIO, A. and ENGEL, MS., 2012. Two new species of Eugossa from South America, with notes on their taxonomic affinities (Hymenoptera, Apidae). ZooKeys, vol. 221, p. 63-79. http://dx.doi.org/10.3897/zookeys.221.3659

LAURANCE, WF., 2009. Conserving the hottest of the hotspots. Biological Conservation, vol. 142, p. 1137. http://dx.doi. org/10.1016/j.biocon.2008.10.011

MELO, AMC., 2005. Gradientes ambientais e a comunidade de abelhas Euglossina (Hymenoptera, Apidae) em fragmentos de Mata Atlântica intercalados por uma matriz de eucaliptais no extremo sul da Bahia. Salvador: Universidade Federal da Bahia. 116 p. Unpublished M.Sc. Thesis.

MITTERMEIER, RA., MYERS, N., GIL, PR. and MITTERMEIER, CG., 1999. Hot spots: Earth's Biologically Richest and Most Endangered Terrestrial Ecoregions. Mexico: CEMEX. 430 p.
MOURE, JS., 1996. Notas sobre algumas espécies de abelhas da Bahia, Brasil (Hymenoptera, Apoidea). Revista Brasileira de Zoologia, vol. 12, p. 467-470.

MYERS, N., 1988. Threatened biotas: "hot spots" in tropical forests. The Environmentalist, vol. 8, p. 187-208. http://dx.doi. org/10.1007/BF02240252

NEMÉSIO, A., 2009. Orchid bees (Hymenoptera: Apidae) of the Brazilian Atlantic Forest. Zootaxa, vol. 2041, p. 1-242.

-, 2010a. Eulaema (Apeulaema) felipei sp. n. (Hymenoptera: Apidae: Euglossina): a new forest-dependent orchid bee found at the brink of extinction in northeastern Brazil. Zootaxa, vol. 2424, p. 51-62.

-, 2010b. The orchid-bee fauna (Hymenoptera: Apidae) of a forest remnant in northeastern Brazil, with new geographic records and an identification key to the known species of the Atlantic Forest of northeastern Brazil. Zootaxa, vol. 2656, p. 55-66.

-, 2011a. The orchid-bee fauna (Hymenoptera: Apidae) of a forest remnant in southern Bahia, Brazil, with new geographic records and an identification key to the known species of the area. Zootaxa, vol. 2821, p. 47-54

-, 2011b. Euglossa marianae sp. n. (Hymenoptera: Apidae): a new orchid bee from the Brazilian Atlantic Forest and the possible first documented local extinction of a forest dependent orchid bee. Zootaxa, vol. 2892, p. 59-68.

-, 2011c. Exaerete salsai sp. n. (Hymenoptera: Apidae): a new orchid bee from eastern Brazil. Zootaxa, vol. 2967, p. 12-20.

-, 2011d. Euglossa bembei sp. n. (Hymenoptera: Apidae): a new orchid bee from the Brazilian Atlantic Forest belonging to the Euglossa cybelia Moure, 1968 species group. Zootaxa, vol. 3006, p. 43-49.

-, 2011e. Rediscovered after forty-two years: the rare orchid bee Eufriesea brasilianorum (Hymenoptera: Apidae) of eastern Brazil. North-Western Journal of Zoology, vol. 7, p. 356-359.

-, 2012a. Species of Euglossa Latreille, 1802 (Hymenoptera: Apidae: Euglossina) belonging to the purpurea species group occurring in eastern Brazil, with description of Euglossa monnei sp. n. Zootaxa, vol. 3151, p. 35-52.

-, 2012b. The western limits of the 'Hileia Baiana' for orchid bees (Hymenoptera: Apidae: Euglossina), including seven new records for the state of Minas Gerais, eastern Brazil. Spixiana, vol. 35 , no. 1, p. 109-116.

-, 2013a. The orchid-bee fauna (Hymenoptera: Apidae) of 'Reserva Biológica de Una', a hotspot in the Atlantic Forest of southern Bahia, eastern Brazil. Brazilian Journal of Biology, vol. 73, n. 2, p. 347-352.

-, 2013b. Are orchid bees at risk? First comparative survey suggests declining populations of forest-dependent species. Brazilian Journal of Biology, vol. 73, n. 2, p. 367-374.

-, 2013c. The orchid-bee faunas (Hymenoptera: Apidae) of two Atlantic Forest remnants in southern Bahia, eastern Brazil. Brazilian Journal of Biology, vol. 73, n. 2, p. 375-381.

NEMÉSIO, A., CERÂNTOLA, NCM., VASCONCELOS, HL., NABOUT, JC., SILVEIRA, FA. and DEL LAMA, MA., 2012. Searching for Euglossa cyanochlora Moure, 1996 (Hymenoptera: Apidae), one of the rarest bees in the world. Journal of Insect Conservation, vol. 16, no. 5, p. 745-755. http://dx.doi.org/10.1007/ s10841-012-9459-2

NEMÉSIO, A. and ENGEL, MS., 2012. Three new cryptic species of Euglossa (Glossurella) from Brazil (Hymenoptera, Apidae). ZooKeys, vol. 222, p. 47-68. PMid:23129986 PMCid:3459030. http://dx.doi.org/10.3897/zookeys.222.3382 
NEMÉSIO, A. and MORATO, EF., 2006. The orchid-bee fauna (Hymenoptera: Apidae) of Acre state (northwestern Brazil) and a re-evaluation of euglossine bait-trapping. Lundiana, vol. 7, p. 59-64.

NEMÉSIO, A. and RASMUSSEN, C., 2011. Taxonomic issues in the orchid bees (Hymenoptera: Apidae: Euglossina), and an updated catalogue. Zootaxa, vol. 3006, p. 1-42.

NEMÉSIO, A. and SILVEIRA, FA., 2004. Biogeographic notes on rare species of Euglossina (Hymenoptera: Apidae: Apini) occurring in the Brazilian Atlantic Rain Forest. Neotropical Entomology, vol. 33, p. 117-120. http://dx.doi.org/10.1590/ S1519-566X2004000100021

-, 2006a. Deriving ecological relationships between host and parasitic species - an example with orchid bees. Journal of Biogeography, vol. 33, p. 91-97. http://dx.doi.org/10.1111/j.13652699.2005.01370.x

-, 2006b. Edge effects on the orchid-bee fauna (Hymenoptera: Apidae) at a large remnant of Atlantic Forest in southeastern Brazil. Neotropical Entomology, vol. 35, p. 313-323. http://dx.doi. org/10.1590/S1519-566X2006000300004

-, 2006c. First record of Eulaema helvola (Hymenoptera: Apidae: Euglossina) for the state of Minas Gerais: biogeographic and taxonomic implications. Neotropical Entomology, vol. 35, p. 418420. http://dx.doi.org/10.1590/S1519-566X2006000300021

-, 2007a. Orchid bee fauna (Hymenoptera: Apidae: Euglossina) of Atlantic Forest fragments inside an urban area in southeastern Brazil. Neotropical Entomology, vol. 36, p. 186-191. http://dx.doi. org/10.1590/S1519-566X2007000200003

-, 2007b. Diversity and distribution of orchid bees (Hymenoptera: Apidae: Euglossina) with a revised checklist of their species. Neotropical Entomology, vol. 36, p. 874-888. http://dx.doi. org/10.1590/S1519-566X2007000600008

-, 2010. Forest fragments with larger core areas better sustain diverse orchid bee faunas (Hymenoptera: Apidae: Euglossina). Neotropical Entomology, vol. 39, p. 555-561. http://dx.doi. org/10.1590/S1519-566X2010000400014

NEVES, EL. and VIANA, BF., 2003. A fauna de abelhas da subtribo Euglossina (Hymenoptera: Apidae) do estado da Bahia, Brasil. In MELO, GAR. and ALVES-DOS-SANTOS, I. (Eds.). Apoidea Neotropica: Homenagem aos 90 anos de Jesus Santiago Moure. Criciúma: Universidade do Extremo Sul Catarinense. p. 223-229.

OLIVEIRA, ML., 2008. Catálogo comentado das espécies de abelhas do gênero Eulaema Lepeletier, 1841 (Hymenoptera: Apidae). Lundiana, vol. 8, p. 113-136.

OLIVEIRA, ML. and CAMPOS, LAO., 1996. Preferência por estratos florestais e por substâncias odoríferas em abelhas Euglossinae (Hymenoptera, Apidae). Revista Brasileira de Zoologia, vol. 13, p. 1075-1085. http://dx.doi.org/10.1590/ S0101-81751996000400025

PACHECO, JF., WHITNEY, BM. and GONZAGA, LP., 1996. A new genus and species of furnariid (Aves: Furnariidae) from the cocoa-growing region of southeastern Bahia, Brazil. The Wilson Bulletin, vol. 108, p. 397-433.

PEARSON, DL. and DRESSLER, RL., 1985. Two-year study of male orchid bee (Hymenoptera: Apidae: Euglossini) attraction to chemical baits in lowland south-eastern Perú. Journal of Tropical Ecology, vol. 1, p. 37-54. http://dx.doi.org/10.1017/ S0266467400000067

PIELOU, EC., 1975. Ecological diversity. New York: John Wiley \& Sons. 165 p.
RAW, A., 1989. The dispersal of euglossine bees between isolated patches of eastern Brazilian wet Forest. Revista Brasileira de Entomologia, vol. 33, p. 103-107.

RASMUSSEN, C., 2009. Diversity and abundance of orchid bees (Hymenoptera: Apidae, Euglossini) in a tropical rainforest succession. Neotropical Entomology, vol. 38, p. 66-73. http:// dx.doi.org/10.1590/S1519-566X2009000100006

REBÊLO, JMM. and GARÓFALO, CA., 1991. Diversidade e sazonalidade de machos de Euglossini (Hymenoptera, Apidae) e preferência por iscas odores em um fragmento de floresta no sudeste do Brasil. Revista Brasileira de Biologia, vol. 51, p. 787-799.

-, 1997. Comunidades de machos de Euglossinae (Hymenoptera, Apidae) em matas semidecíduas do nordeste do estado de São Paulo. Anais da Sociedade Entomológica do Brasil, vol. 26, p. 243-256. http://dx.doi.org/10.1590/S0301-80591997000200005

SAMBUICHI, RHR., OLIVEIRA, RM., MARIANO NETO, E., THÉVENIN, JMR., JESUS JUNIOR, CP., OLIVEIRA, RL. and PELIÇÃO, LC., 2008. Status de conservação de dez árvores endêmicas da Floresta Atlântica do sul da Bahia - Brasil. Natureza \& Conservação, vol. 6, p. 90-108.

SNEATH, PHA. and SOKAL, RR., 1973. Numerical taxonomy. The principles and practice of numerical classification. San Francisco: W. H. Freeman. 573 p.

STORCK-TONON, D., MORATO, EF. and OLIVEIRA, ML., 2009. Fauna de Euglossina (Hymenoptera: Apidae) da Amazônia SulOcidental, Acre, Brasil. Acta Amazonica, vol. 39, p. 693-706. http://dx.doi.org/10.1590/S0044-59672009000300026

STORCK-TONON, D., SILVA, MV. and MORATO, EF., 2011. Checklist of orchid bees (Hymenoptera: Apidae) of "Lago do Silêncio" area, Boca do Acre, Amazonas, Brazil. Check List, vol. 7 , p. 648-651.

THOMAS, WW. and CARVALHO, AM., 2003. Zoneamento Ecológico do Sudeste da Bahia, Brasil (mapa em formato digital). In PRADO, PI., LANDAU, EC., MOURA, RT., PINTO, LPS., FONSECA, GAB. and ALGER, K. (Orgs.). Corredor de Biodiversidade da Mata Atlântica do Sul da Bahia. Ilhéus: IESB/ Conservation International. CD-ROM.

THOMAS, WW., CARVALHO, AM., and HERRERA-MacBRYDE, O., 1997. Atlantic moist forest of southern Bahia: South-eastern Brazil. In World Wide Fund for Nature - WWF and International Union for Conservation of Nature - IUCN. Centers of plant diversity: A guide and strategy for their conservation. Cambridge: IUCN Publications Unit. vol. 3, p. 364-368.

THOMAS, WW., CARVALHO, AM., AMORIM, AMA., GARRISON, J. and ABERLÁEZ, AL., 1998. Plant endemism in two forests in southern Bahia. Biodiversity and Conservation, vol. 7, p. 311-322. http://dx.doi.org/10.1023/A:1008825627656 TOCHER, MD., GASCON, C. and ZIMMERMANN, BL., 1997. Fragmentation effects on a Central Amazonian frog community: a ten-year study. In LAWRENCE, WF. and BIERREGAARD JUNIOR, RO. (Eds.). Tropical Forest Remnants: ecology, management, and conservation of fragmented communities. Chicago: Chicago University Press. p. 124-137.

TONHASCA JUNIOR, A., BLACKMER, JL. and ALBUQUERQUE, GS., 2002. Abundance and diversity of euglossine bees in the fragmented landscape of the Brazilian Atlantic Forest. Biotropica, vol. 34, p. 416-422.

VOGEL, S., 1966. Parfümsammelnde Bienen als Bestäuber von Orchidaceen und Gloxinia. Österreiches Bot. Zeitschrift, vol. 113, p. 302-361. http://dx.doi.org/10.1007/BF01373435

WOLDA, H., 1981. Similarity indices, sample sizes and diversity. Oecologia, vol. 50, p. 296-302. http://dx.doi.org/10.1007/ BF00344966 